\title{
Experimental investigation on the use of steel-concrete bond tests for estimating axial compressive strength of concrete: Part 1
}

\section{Investigação experimental sobre o uso de ensaios de aderência aço-concreto para estimativa da resistência à compressão axial do concreto: Parte 1}
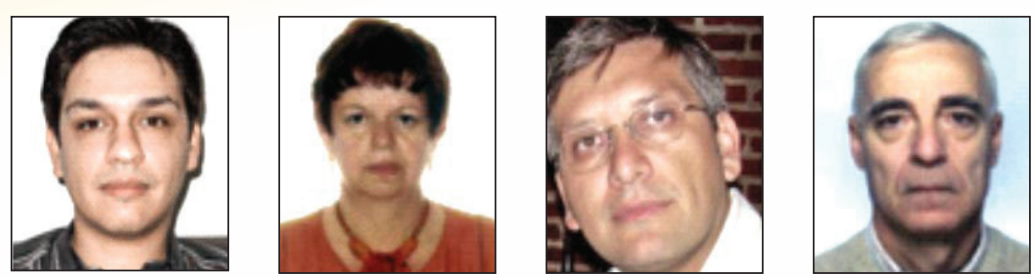

B. V. SILVA a

dovalesilva@hotmail.com

M. P. BARBOSA

mbarbosa@dec.feis.unesp.br

L. C. P. SILVA FILHO ${ }^{\circ}$

Icarlos66@gmail.com

M. S. LORRAIN a

michel.lorrain@insa-toulouse.fr

\begin{abstract}
This study analyzes the feasibility of using steel-concrete bond tests for determining the compressive strength of concrete in order to use it as a complement in the quality control of reinforced concrete. Lorrain and Barbosa (2008) [14] and Lorrain et al. (2011) [15] justify the use of a modified bond test, termed APULOT, to estimate the compressive strength of concrete, hence increasing the possibilities for the technological control of reinforced concrete for constructions. They propose an adaptation of the traditional pull-out test (POT) method, standardized by the CEB / FIP RC6: 1983 [8], because it is a low complexity and low cost test. To enable the use of the APULOT test as a technological control test of concrete at construction sites requires determining its methodology and adapting the experimental laboratory practice to the construction itself. The aim of this study is to evaluate the possibility of conducting compressive strength estimates using bond stress data obtained by the traditional pull-out tests (POT). Thus, two concrete compositions of different classes were tested at 3,7 and 28 days. Ribbed bar specimens (nominal diameters of 8,10 and $12.5 \mathrm{~mm}$ ) were also used in the preparation stage, totaling 108 POT tests. The results show that the correlation between the maximum bond stress and the compressive strength of concrete is satisfactory in predetermined cases, at all ages tested, reinforcing the purpose of consolidating this test as a complementary alternative to control the quality of reinforced concrete. In the second part of this paper the test results obtained with the APULOT method are presented and discussed.
\end{abstract}

Keywords: steel-concrete bond; pull-out; APULOT; compressive strength of concrete.

\section{Resumo}

A presente pesquisa se propõe a estudar a viabilidade do uso de ensaios de aderência aço-concreto para estimativa da resistência à compressão axial do concreto, com o objetivo de empregá-los como um complemento no controle de qualidade do concreto armado. Lorrain e Barbosa (2008) [14] e Lorrain et al. (2011) [15] justificam a utilização de um ensaio de aderência modificado, denominado APULOT, para estimar a resistência à compressão do concreto, incrementando as possibilidades de controle tecnológico do concreto armado em canteiros de obras. Os mesmos propõem uma adaptação do método pull-out test (POT) tradicional, normalizado pela CEB/FIP RC6:1983 [8], por ser este um ensaio de baixa complexidade e de custo reduzido. Para viabilizar o uso do ensaio APULOT como ensaio de controle tecnológico do concreto em canteiro de obras é necessário definir um padrão para o mesmo e adaptá-lo da prática experimental do laboratório para o campo. O presente trabalho buscou avaliar num primeiro momento, a potencialidade de efetuar estimativas da resistência à compressão a partir dos dados da tensão de aderência obtidos com uso do POT. Para tanto, foram ensaiadas 2 composições de concreto de classes distintas, aos 3,7 e 28 dias. Foram, ainda, usadas na confecção dos corpos de prova barras nervuradas com diâmetros nominais de 8,10 e $12,5 \mathrm{~mm}$, totalizando 108 ensaios do tipo POT. Os resultados obtidos mostram que, sob condições padronizadas de ensaio, a correlação entre a tensão máxima de aderência e a resistência à compressão do concreto é satisfatória, em todas as idades ensaiadas, fortalecendo o propósito de consolidar este ensaio como uma alternativa complementar para controle de qualidade do concreto armado. Na segunda parte deste trabalho serão apresentados e discutidos resultados de ensaios realizados com o método APULOT.

Palavras-chave: aderência aço-concreto; pull-out; APULOT; resistência à compressão do concreto.

Doutorando, Univesidade Federal do Rio Grande do Sul, Programa de Pós Graduação em Engenharia Civil, dovalesilva@hotmail.com, Porto Alegre, Brasil. Professora Associada, Univesidade Estadual Paulista, Departamento de Engenharia Civil, mbarbosa@dec.feis.unesp.br, Ilha Solteira, Brasil. Professor Doutor, Univesidade Federal do Rio Grande do Sul, Programa de Pós Graduação em Engenharia Civil, Icarlos66@gmail.com, Porto Alegre, Brasil.

Professeur, Institut National des Sciences Apliquées, Département de Génie Civil, michel.Iorrain@insa-toulouse.fr, Toulouse, França. 


\section{Introduction}

In civil construction one of the best known and most applied tests to control the quality of reinforced concrete is the axial compression test of specimens, which are usually molded upon receiving the concrete prior to casting. This type of test is standardized in Brazil by ABNT NBR 5739:2007 [5] and, an estimate of the compressive strength of concrete is obtained through it, which the main design and structural control parameter.

However, to perform this test requires appropriate equipment and trained technicians, which are not usually available at construction sites, resulting in the construction company having to rely on specialized laboratories. Furthermore, in order to obtain reliable results it is necessary to be careful and control a variety of factors, such as molding, storage, capping and loading speed of the specimen. Any deviations from the standard test procedure, or uniformity capping problems, which result in stress concentrations, can significantly affect the results, especially in high strength concrete. Recognizing the importance and usefulness of the traditional test for determining the axial compressive strength of the concrete, but aware of the experimental details, which can affect the quality and accuracy of the results obtained, a group of researchers led by Professor Michel Lorrain (INSA Toulouse), have examined the possibility of using a steel-concrete bond test adapted to the construction site to estimate the compressive strength of concrete. [14] As explained by Lorrain et al. (2011) [15], this group, made up of researchers from France, Brazil and other countries, has been working on the improvement of a new test method, based on the steel-concrete bond test: pull-out test (POT), initially proposed as a recommendation of the CEB / FIP RC6: 1983 [8], which is cha- racterized by its simplicity and reduced cost.

The new method was termed APULOT (Appropriate Pull-Out Test) and in the tests performed it has shown good reliability and adequate capacity to estimate compressive strength [19]. Among the advantages of the proposed method we can highlight its execution simplicity, its reduced recommended time to perform the test (from 28 days to 7 days) and the possibility of measuring not only the strength but also the behavior of steel-concrete bond, an important factor for the proper performance of reinforced concrete structures. According to Ferguson (1966) and FIB (2000) understanding the bond behavior is a key factor to properly understand the calculating norms of the anchorage length and the overlapping amendments of reinforced bars, and for calculating the displacements, considering the stiffening effect by traction, cracking control and the minimum amount of reinforcement bars $[9,10]$. But, our in our study the main aspect of interest is that the strength of the reinforced concrete is a determining factor in the behavior of steel-concrete bond. The working hypothesis of the APULOT project is that if the test is conducted under controlled and standardized conditions, this relationship becomes even more evident and robust, thus allowing to estimate the compressive strength of concrete from maximum bond strength data.

Because the initial results are positive, the development, refinement and validation process of the APULOT tests have advanced, because it is considered that they may eventually become a complementary alternative to the major axial compression tests traditionally used in technological control of concrete or become the primary way to control the quality of concrete at the construction site. The APULOT group has studied different aspects associated with the test, attempting to identify the most influential factors in

Figure 1 - Schematic drawing of the POT test method (13)

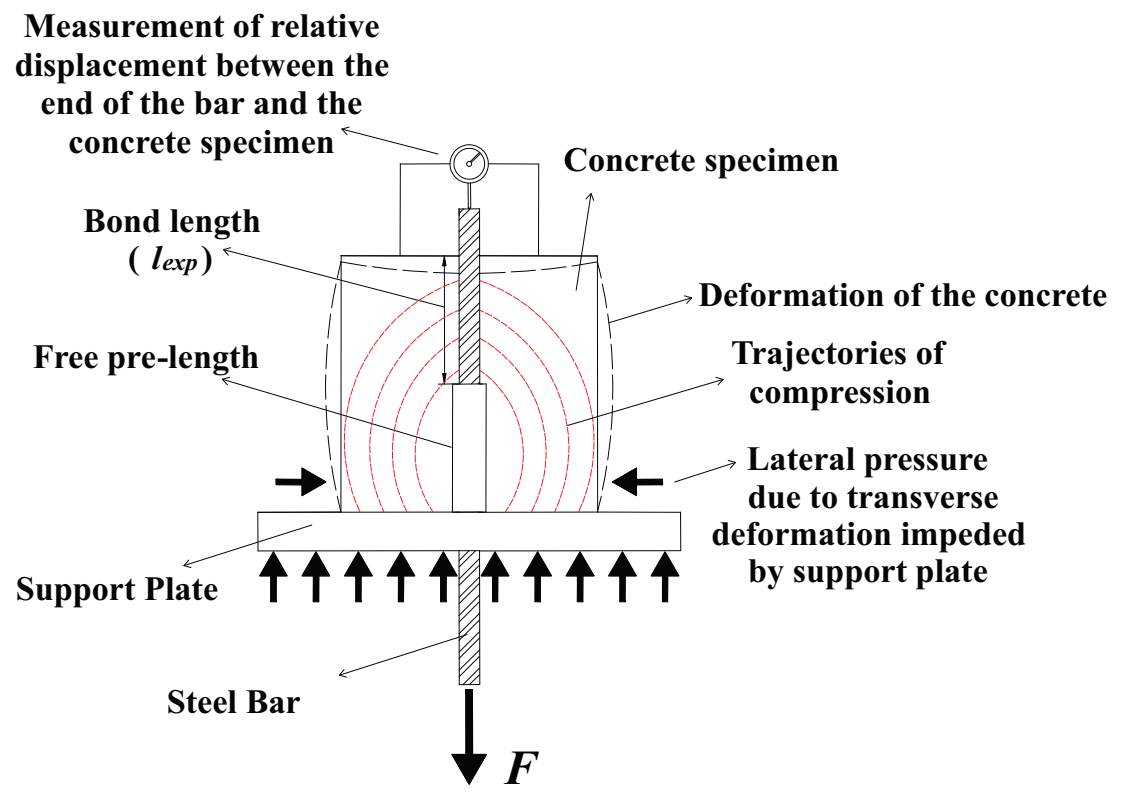


the fc $\mathrm{x}$ Tb relationship (compressive strength $\mathrm{x}$ bond strength). This knowledge is fundamental to support the formalization of a standard test procedure that can be performed in real construction sites, providing support for an eventual standardization of method. Within this scope, the first part of this paper presents the experimental results of the tests using the traditional pull-out test (POT) method, aiming to evaluate its capacity to estimate the compressive strength of concrete in different classes based on the pullout test results, and at the same time evaluate the effect of changing the diameter of the test bar. The aim was to confirm the validity of the fundamental work hypothesis and establish the prerequisites for determining the standard APULOT test procedure considering aspects related to its eventual implementation at construction sites. The second part of this paper presents and discusses the test results obtained with the APULOT method.

\section{Considerations about steel-concrete bonding}

There are several factors that influence the steel-concrete bonding. The ACl 408R: 2003 [1] mentions the following: type of configuration of the bar ribs, the bar diameter, the state of the bar surface (deterioration), the location of the bar at casting time - horizontal or vertical, the water cement ratio $(\mathrm{w} / \mathrm{c})$, the mechanical strength of the concrete, mineral additions such as pozzolanic materials, the physicochemical characteristics of the materials used in the concrete, the compaction and rupture age, among other factors.

There are various kinds of tests for quantifying steel-concrete bonding. The most widely used, due to its simplicity and effectiveness, is the so called pull-out test (POT). One of the parameters the test determines is the maximum bond stress $\left(\tau_{\text {bmáx }}\right)$, which is actually an average nominal value obtained by dividing the maximum pullout force applied to cause slipping of the bar by the anchoring side surface of the steel bar [8].

Although it is simple and convenient, using the POT test has limitations when one wants to accurately estimate the effective value of the bond strength to determine, for example, minimum anchor lengths to be used in structural elements. This type of test does not evaluate the effect of confinement on the concrete due to the presence of reinforced cement and does not consider that the pullout may be associated with flexural strain of the steel-concrete association, which changes how the bar interacts with the surrounding concrete.

Figure 1 shows a schematic drawing of the operation of the POT test adapted from Leonhardt and Mönnig (1977) [13]. According to the figure, the standard test procedure eventually generates distortions, because during the test the support plates place the concrete under compression, creating restrictions on transverse deformations of the specimen. The figure indicates the compression trajectories and the deformation prevention in the transverse support plate that appears when this test configuration is used, which can result in the possibility that the bond strength is overestimated. Although the test has limitations when the objective is to determine the maximum effective bond strength in structural elements, it proves to be very attractive for the technological control of concrete. Some researchers state that the correlation between the compressive strength of concrete and the strength of the steel-concrete connection is directly proportional [18]. Lorrain and Barbosa (2008) [14] and Lorrain et. al (2011) [15] analyzed the correlation betwe-

\section{Figure 2 - Correlation curve between the maximum bond strength and compression strength (15)}

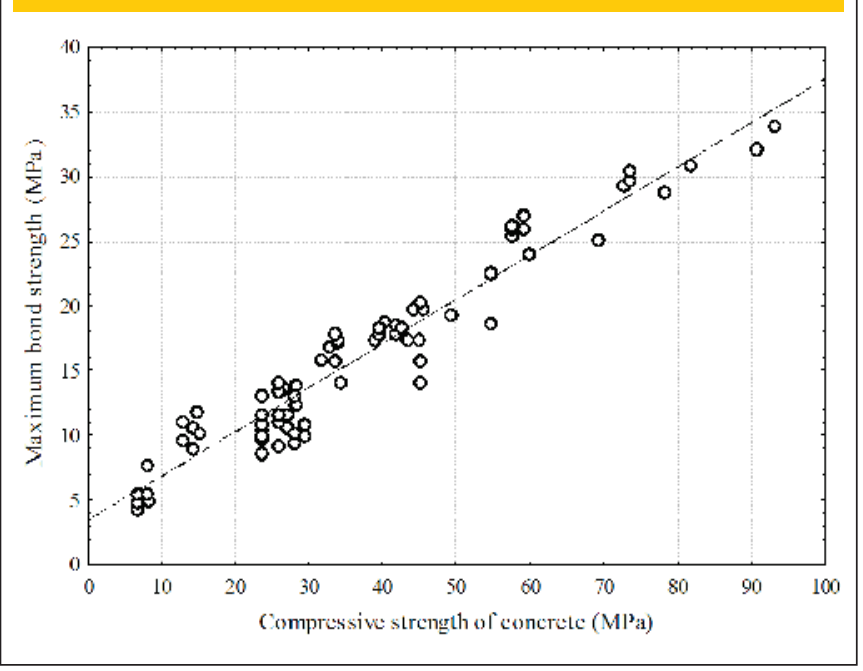

en the compressive strength $\left(f_{c}\right)$ and the maximum bond strength $\left(\tau_{b \max }\right)$ confirming that, if only the results of tests in which the slip occurred are considered, the relationship is robust.

Figure 2 shows part of the results of the correlation between the maximum bond strength $\left(\tau_{\text {bmáx }}\right)$ and the axial compressive strength of the concrete analyzed by Lorrain et al. (2011). It was prepared only with the POT test results, which showed the sliding of the steel bar in relation to the concrete.

Based on these observations, the authors suggest the use of steel-concrete bond tests to estimate the compressive strength, that is, as an alternative to control the quality of concrete. Another interesting aspect associated with the possible use of the bond test in the technological control of concrete is that the force necessary to cause slipping of the bar is approximately ten to twenty times less than that required to rupture a normalized cylinder of $15 \times 30 \mathrm{~cm}$ in an axial compression test. This means that the test equipment at the construction site can be lighter and simpler. [15]

\section{Materials and methods}

This section presents the characteristics of the materials used in the experimental program and the procedures used in the bond tests conducted with the POT method.

\subsection{Concrete characteristics}

The materials that compose the concrete used in the study, with the exception of superplasticizer, were characterized at the Civil Engineering CESP Laboratory (LCEC), in Ilha Solteira, SP, Brazil. The cement used was CPV-ARI (high early strength Portland cement) with specific mass of $3.05 \mathrm{~g} / \mathrm{cm}^{3}$, specific apparent mass of $0.90 \mathrm{~g} / \mathrm{cm}^{3}$ and specific surface area (Blaine) of $4768 \mathrm{~cm}^{2} / \mathrm{g}$. The fine aggregate was one medium sand with fineness modulus equal to 2.15 ; specific mass of $2.61 \mathrm{~g} / \mathrm{cm}^{3}$, and maximum nominal size of $4.75 \mathrm{~mm}$. The coarse aggregate was crushed basaltic, with fineness modulus equal to 6.48 , specific mass of $2.90 \mathrm{~g} / \mathrm{cm}^{3}$ and 
Table 1 - Mechanical characterization of concrete

\begin{tabular}{ccccc}
$\begin{array}{c}\text { Composition } \\
\text { of concrete }\end{array}$ & $\begin{array}{c}\text { Rupture } \\
\text { age (days) }\end{array}$ & $\begin{array}{c}\text { Compressive strength } \\
\mathrm{f}_{\mathrm{cm}}(\mathrm{MPa})\end{array}$ & $\begin{array}{c}\text { Tensile strength by } \\
\text { diametral compression } \mathrm{f}_{\mathrm{cm}}(\mathrm{MPa})\end{array}$ & $\begin{array}{c}\text { Elastic modulus } \\
\mathrm{E}_{\mathrm{c}}(\mathrm{GPa})\end{array}$ \\
$\mathrm{T} 25$ & 03 & $17.1 \pm 1.0$ & $2.54 \pm 0.04$ & $31.60 \pm 2.89$ \\
& 07 & $21.2 \pm 1.7$ & $2.72 \pm 0.06$ & $32.64 \pm 0.46$ \\
& 28 & $27.8 \pm 1.6$ & $3.28 \pm 0.23$ & $36.10 \pm 2.82$ \\
$\mathrm{~T} 45$ & 03 & $34.5 \pm 1.4$ & $3.75 \pm 0.17$ & $40.09 \pm 1.65$ \\
& 07 & $40.1 \pm 1.6$ & $4.10 \pm 0.12$ & $41.10 \pm 0.53$ \\
& 28 & $49.3 \pm 1.6$ & $4.60 \pm 0.22$ & $46.85 \pm 0.28$ \\
\hline
\end{tabular}

a maximum nominal size of $19.0 \mathrm{~mm}$. The additive used was a polycarboxylate-based third-generation superplasticizer, which according to the manufacturer has a density of $1.08 \mathrm{~g} / \mathrm{cm}^{3}$, solid content of $30 \%$ and a pH of 4.42 .

After characterizing the materials a dosage method based on IPT / EPUSP was performed [12] in order to obtain two concrete mixtures corresponding to classes 25 and $45 \mathrm{MPa}$. The intention was to work with two strength levels to evaluate whether it was possible to estimate the compressive strength by the bond strength in an equivalent strength range, currently used in concrete constructions. To facilitate identification, these compositions were denominated as T25 and T45. The slump was fixed at $10 \pm 2 \mathrm{~cm}$. In order to limit the $\mathrm{w} / \mathrm{c}$ ratio it accepted superplasticizer additive content of $0.26 \%$ in relation to the cement mass, for both compositions. The resulting compositions were: T25 (1:2.90:3.07) with w/c $=0.61$ and T45 $(1: 1,53: 1,98)$ with $w / c=0.37$.

To characterize the concrete produced, compressive strength tests were performed according to ABNT NBR 5739:2007 [5]; tensile strength of concrete by diametral compression according to ABNT NBR 7222:2010 [4], and elastic modulus of elasticity of concrete, according to ABNT NBR 8522:2008 [3].

For each rupture age three cylindrical specimens $(10 \times 20 \mathrm{~cm})$ were molded, according to ABNT NBR 5738:2003 [6]. They were compacted using a vibrating table completed in two concrete layers of 10 s duration per layer. The cure was performed in a humid chamber at relative humidity above $95 \%$ and temperature of $23 \pm 2{ }^{\circ} \mathrm{C}$.

At rupture time the specimens were tested in a hydraulic press (Wolpert) with load capacity of $1000 \mathrm{kN}$. Table 1 shows the results, indicating the average and the standard deviation of the sample consisting of three specimens for each age and type of test. Table 1 shows the average compressive strengths $\left(f_{c m}\right)$ reached values of $27.8 \mathrm{MPa}$ and $49.3 \mathrm{MPa}$, respectively, at 28 days, meeting the specifications required for each class of concrete composition.

\subsection{Characteristics of steel bars}

The ribbed steel bars (CA-50), used to generate the specimens for the bond tests, were characterized according to ABNT NBR 7480:2007 [2]. This standard specifies that the yield stress of the steel bars should be at least $500 \mathrm{MPa}$ and tensile strength $10 \%$ greater than this value. For each diameter tested $(8,10,12.5 \mathrm{~mm})$ three specimens (60 cm long) were tested. The results are shown in Table 2, which shows that the bars are in accordance with the specifications of Brazilian standards.

Aiming to improve the analysis of the geometrical characteristics of the steel bars that affect adherence, it was decided to use a new method of analysis that is widely used in the area of materials design, yet innovative in the area of civil engineering. This technique involves generating a 3D model of the bar by laser resizing using a Digimill 3D model three-dimensional scanner. The data obtained can be processed and transformed to obtain a highly accurate $3 \mathrm{D}$ model, manipulated in a CAD environment.

Figure 3 (a) shows a 3D image generated with the Geomagic Studio software. Figure 3 (b) shows the projection area of the rib plane of this bar. Using this type of treatment can predict the areas and inclinations of the ribs in an innovative and far more accurate manner.

This procedure, used in an original and innovative manner by the LEME research group to study the effects of section losses due to corrosion in the work of Graeff (2007) [11], which was adapted to study the bond of deteriorated bars by Caetano (2008) [7]. Since then it has been used by the APULOT group to characterize in detail steel bar ribs [16, 17, 19]. The APULOT Group believes that disseminating this form of analysis will yield great advances

Table 2 - Characterization results of the steel bars (CA-50)

\begin{tabular}{|ccccc|}
$\begin{array}{c}\text { Nominal diameter } \\
\varnothing(\mathrm{mm})\end{array}$ & $\begin{array}{c}\text { Yield stress } \\
\mathrm{f}_{\mathrm{sy}}(\mathrm{MPa})\end{array}$ & $\begin{array}{c}\text { Failure stregth } \\
\mathrm{f}_{\mathrm{st}}(\mathrm{MPa})\end{array}$ & $\begin{array}{c}\text { Failure strain } \\
\mathrm{A}_{\mathrm{gt}}(\%)\end{array}$ & $\begin{array}{c}\text { Linear mass } \\
(\mathrm{kg} / \mathrm{m})\end{array}$ \\
8 & $625.0 \pm 0.7$ & $777.0 \pm 3.5$ & $16.30 \pm 0.07$ & $0.398 \pm 0.004$ \\
10 & $620.0 \pm 2.1$ & $782.0 \pm 1.4$ & $17.00 \pm 0.07$ & $0.610 \pm 0.005$ \\
12.5 & $580.0 \pm 3.1$ & $743.0 \pm 2.6$ & $17.60 \pm 0.09$ & $0.956 \pm 0.005$ \\
\hline
\end{tabular}




\section{Figure 3 - (a) 3D model of the steel bar and (b) Projected area of the rib}
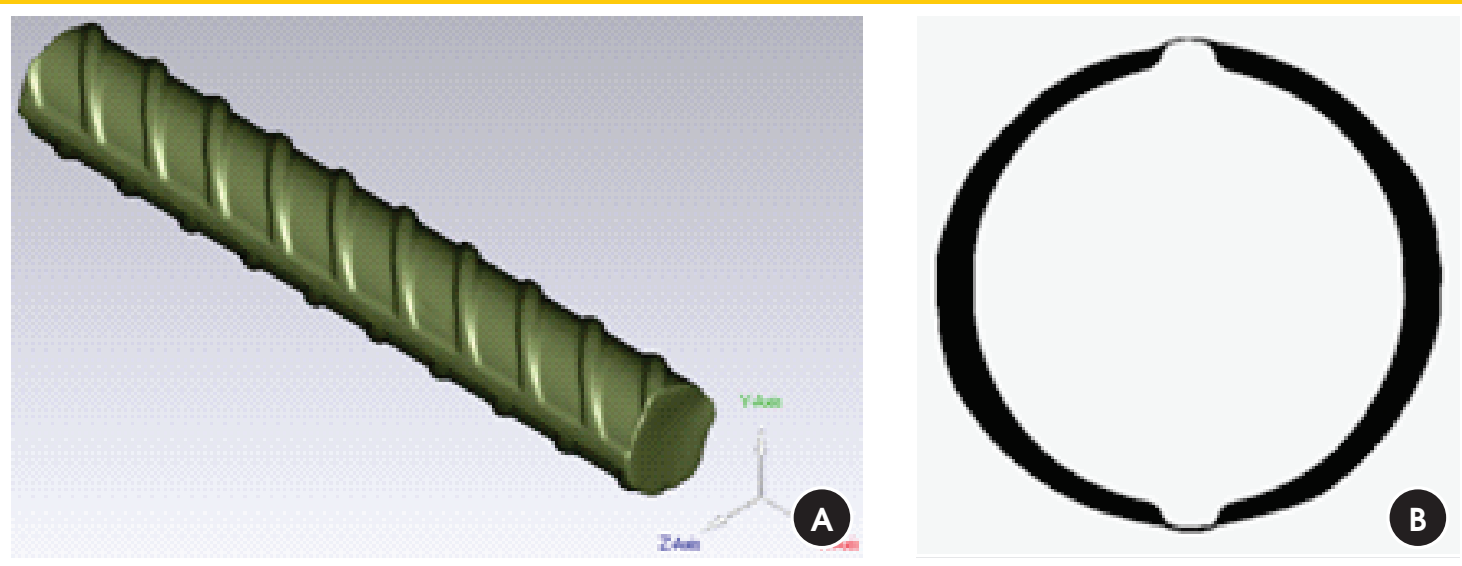

Table 3 - Geometric characteristics of the steel bar ribs

\begin{tabular}{|ccccc|}
$\begin{array}{c}\text { Nominal diameter } \\
\varnothing(\mathrm{mm})\end{array}$ & $\begin{array}{c}\text { Rib height maximum } \\
\mathrm{A}(\mathrm{mm})\end{array}$ & $\begin{array}{c}\text { Rib spacing } \\
e(\mathrm{~mm})\end{array}$ & $\begin{array}{c}\text { Horizontal rib angle } \\
\text { (inclination) } \beta\left({ }^{\circ}\right)\end{array}$ & $\begin{array}{c}\text { Projected } \\
\text { area }\left(\mathrm{mm}^{2}\right)\end{array}$ \\
8 & $0.49 \pm 0.05$ & $5.53 \pm 0.05$ & $52.05^{\circ} \pm 0.63$ & $9.44 \pm 0.05$ \\
10 & $0.75 \pm 0.05$ & $6.71 \pm 0.05$ & $51.86^{\circ} \pm 0.34$ & $16.44 \pm 0.05$ \\
12.5 & $0.97 \pm 0.05$ & $9.03 \pm 0.05$ & $51.89^{\circ} \pm 0.34$ & $28.26 \pm 0.05$ \\
\hline
\end{tabular}

in the study of steel-concrete bond given that it allows a geometric characterization with extreme precision, differentiating the bars regarding the effect of mechanical bond caused by the ribs. Table 3 shows a summary of the geometrical characteristics obtained by analyzing the 3D models of the bars.

\subsection{Steel-concrete bond tests}

To study the steel-concrete bond two concrete compositions were evaluated (T25 and T45), three rupture ages (3, 7 and 28 days) and three diameters of steel bar CA-50 (8 $\mathrm{mm}$ to $10 \mathrm{~mm}$ and 12.5 $\mathrm{mm}$ ). Six specimens were tested for each combination described above, totaling 108 tests. In all concreted bond tests the compressive strength of the concrete was evaluated, as described in item 3.1 , obtaining average compressive strength not exactly equal to the preliminary test shown in Table 1, however with no significant differences. The pull-out test method was performed according to the recommendations of the standard CEB / FIP RC6: 1983 [8], which stipulates that the concrete cube dimensions are equal to ten times the diameter of the bar $(10 \varnothing)$, and the minimum size is $20 \mathrm{~cm}$ and the anchor is fixed at five times the diameter of the bar $(5 \varnothing)$. Figure 4 illustrates the dimensions of the POT test method. With the POT test method the forces in $\mathrm{kN}$ (kilonewtons) are obtained, according to the slide of the steel bar. And according to the recommendations of CEB / FIP RC6: 1983 [8], with this force value divided by the anchorage area of the bar, the bond strength was calculated $(\mathrm{Tb})$, as shown in Equation 1.

$$
\tau_{b}=\frac{F}{\pi . \varnothing \cdot l_{\exp }}
$$

Where $F$ is the pullout force, $\varnothing$ is the diameter of the steel bar and $I_{\text {exp }}$ is the anchorage length of the test. The maximum bond strength

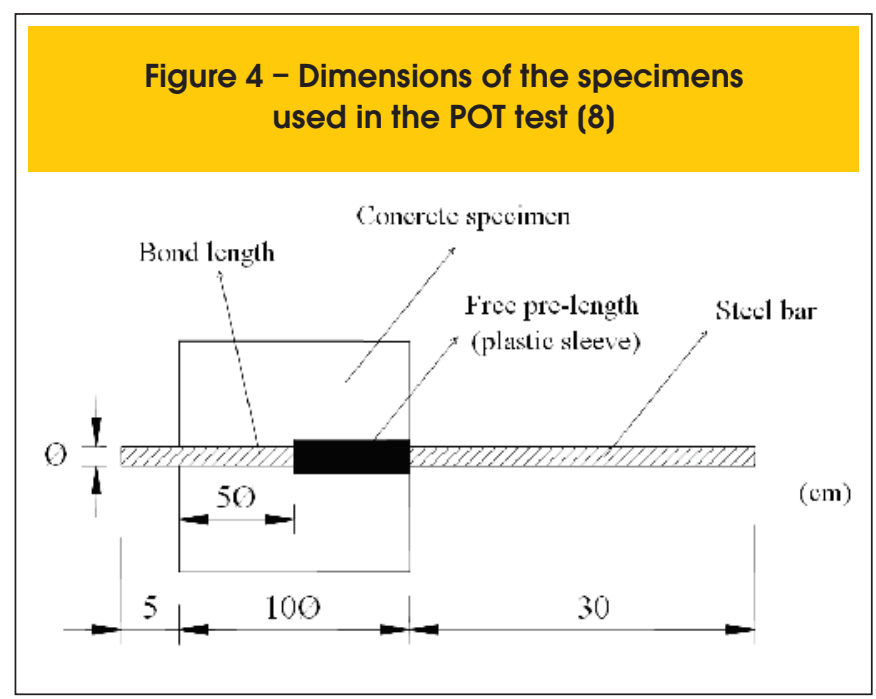


Experimental investigation on the use of steel-concrete bond tests for estimating axial compressive strength of concrete: Part 1

Figure 5 - (a) Metallic mold on a vibrating table. (b) Specimens for the POT method tests
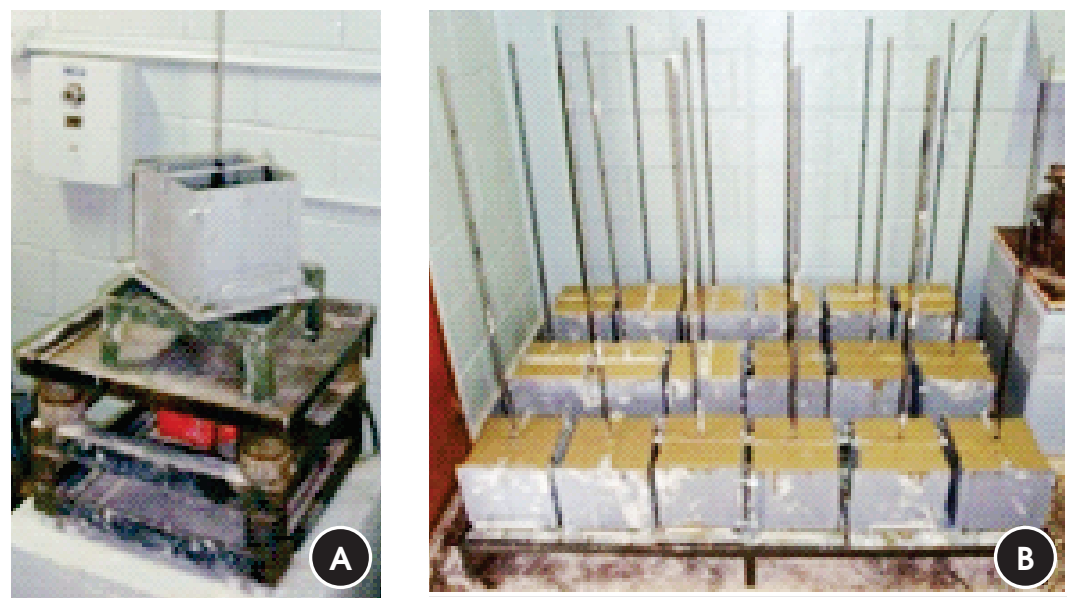

Figure 6 - (a) overview of the pullout and measurement System - (b) System of the POT test method
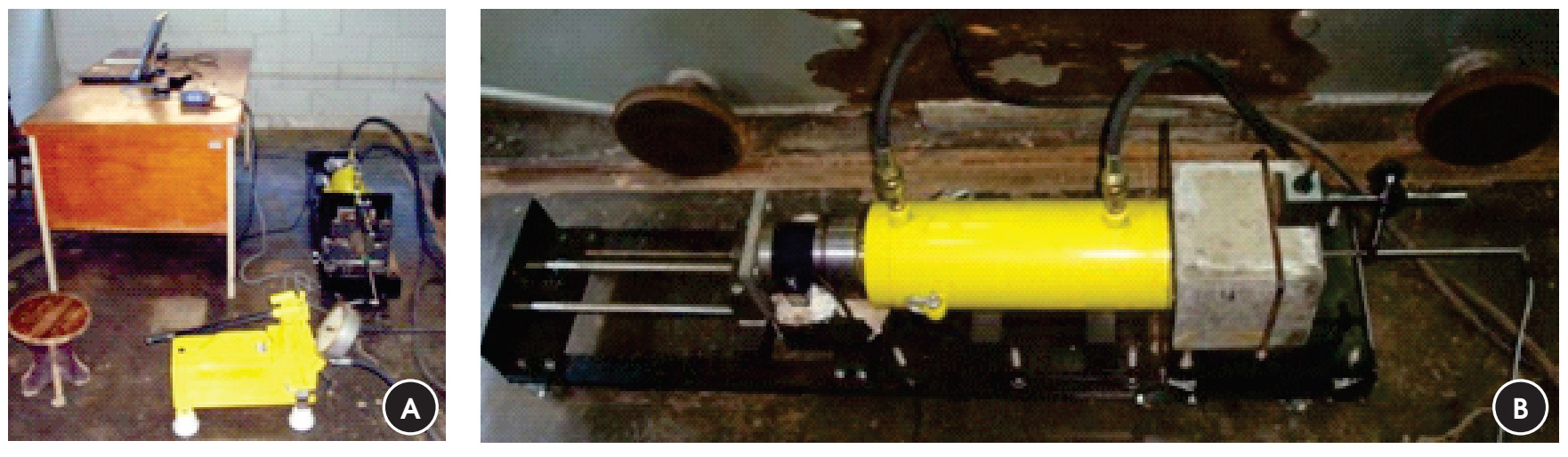

Figure 7 - Schematic of the POT test method (19)

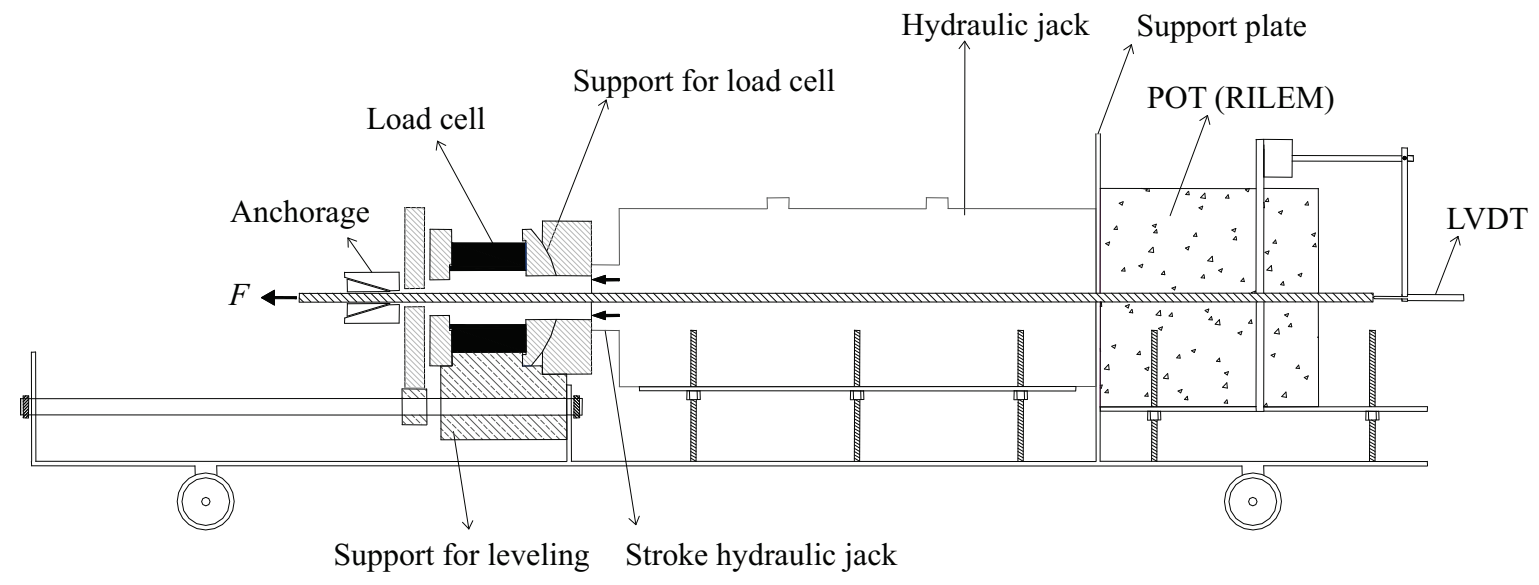


Figure 8 - (a), (b) Photos of the specimens before and after the POT test, illustrating the bond-slip failure mode
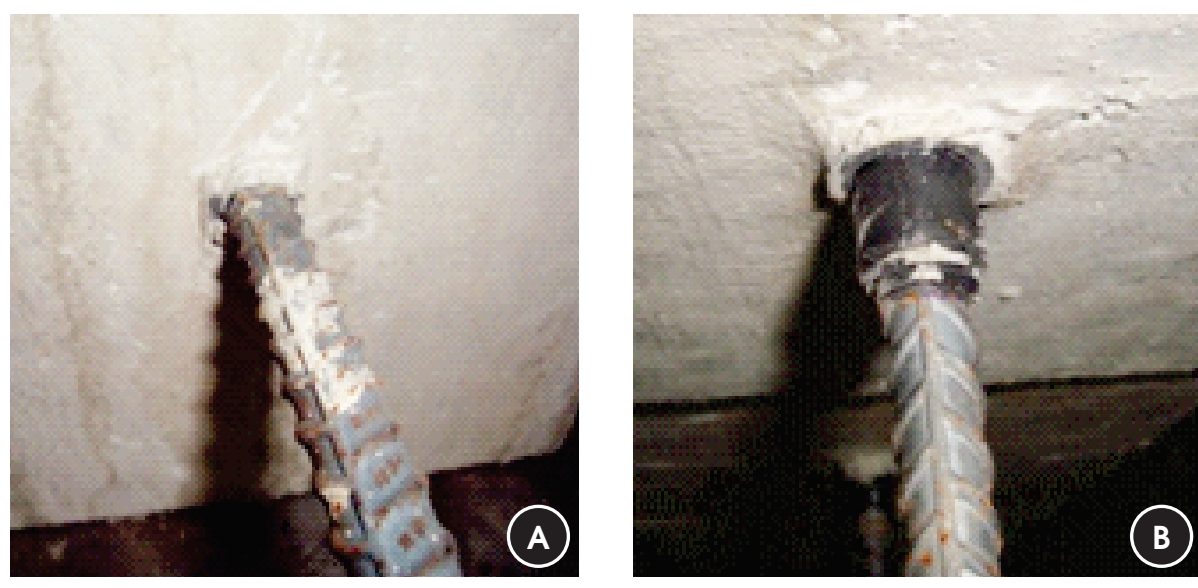

$\left(\tau_{\text {bmáx }}\right)$ was calculated based on the maximum pullout force. Figure 5 shows the metal mold on a vibrating table and the specimens for the POT method tests.

The pullout system for the POT method was assembled on a properly leveled movable support. To apply the force a 600 $\mathrm{kN}$ capacity hydraulic jack was used, connected to a manual pump pressure, to which a pulling force was applied at one end of the bar, which reacted against the specimen. Figure 6 shows an overview of the pullout and measurement system positioned on a table. Figure 7 illustrates a scheme of the POT method.

The pullout force was measured by the load cell and the linear displacement by LVDT (Linear Variable Differential Transformer) as illustrated in Figure 7. These data were collected by the data acquisition system (QuantumX) and visualized through the computer program (CatmanEasy), both from HBM. This system enabled to obtain force curves versus displacement.

\section{Results of steel-concrete bond tests}

This section presents the results from the POT tests, where we analyze the mechanical behavior of steel bars pulled from the concrete through slip curves as a function of bond strength and evaluate the correlation between the maximum bond strength with compressive strength of the concrete by the analysis of variance methodology (ANOVA) which statistically analyzed the results obtained in the POT tests in order to verify the influence of the variables involved in the bond tests.

\subsection{Curves bond strength versus slip of the steel bar}

The mechanical behavior of the specimens was evaluated by the slip curves versus bond strength and by visual verification. This enabled to see in which specimens the bond-slip failure, the concrete splitting failure or yielding of the steel bar occurred. The results showed that the predominant behavior was bond-slip failure. This is explained by the fact that the specimens have concrete cover (c) around the steel bar, adequate to withstand the stresses generated in the POT bond test. Figure 8 shows the bond-slip failure mode after the POT test.

Figures 9,10 and 11 show the differences of bond strength curves versus steel-concrete slip depending on the age and composition of the concrete for the POT test of $8 \mathrm{~mm}, 10 \mathrm{~mm}$ and $12.5 \mathrm{~mm}$, respectively.

With the mechanical behavior of the specimens analyzed by slip curves as a function of bond strength, we performed a correlation analysis between the maximum bond strength and compressive strength of the concrete.

\subsection{Analysis of the correlation between the maximum bond strength $\left(\tau_{\text {bmáx }}\right)$ and compressive strength $\left(f_{c}\right)$}

Table 4 shows the results of the POT bond tests, the composition, age of the concrete and the compressive strength results of the concrete, and the diameter of the steel bar. It should be emphasized that the correlation analysis between variables $\left(\mathrm{T}_{b \operatorname{máx}} \times f_{c}\right)$ is valid only for the results where the bond-slip failure is observed, excluding the results where concrete splitting failure or yielding of the steel bar were observed [15].

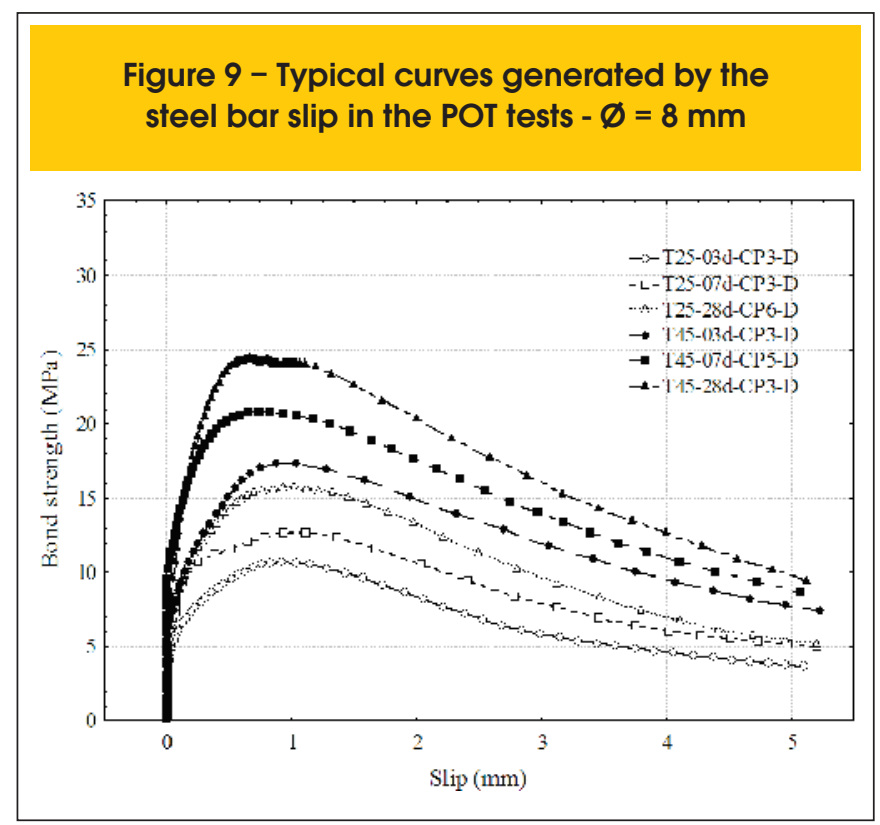


A statistical analysis was performed by the analysis of variance (ANOVA) methodology in the results shown in Table 4 in order to verify the influence of the following factors: (1) steel bar dia-

Figure 10 - Typical curves generated by the steel bar slip in the POT tests $-\varnothing=10 \mathrm{~mm}$

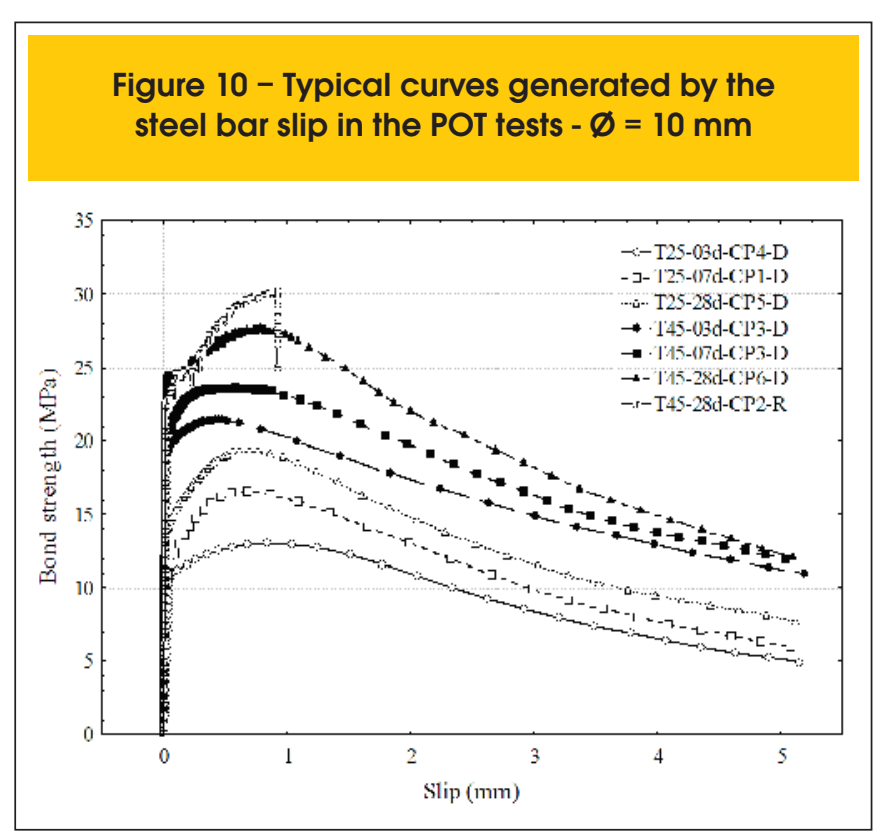

meter, (2) concrete composition, and (3) test age, and how they significantly influence the maximum bond strength. Table 5 shows the analysis of variance results performed with the Statistica 7.0

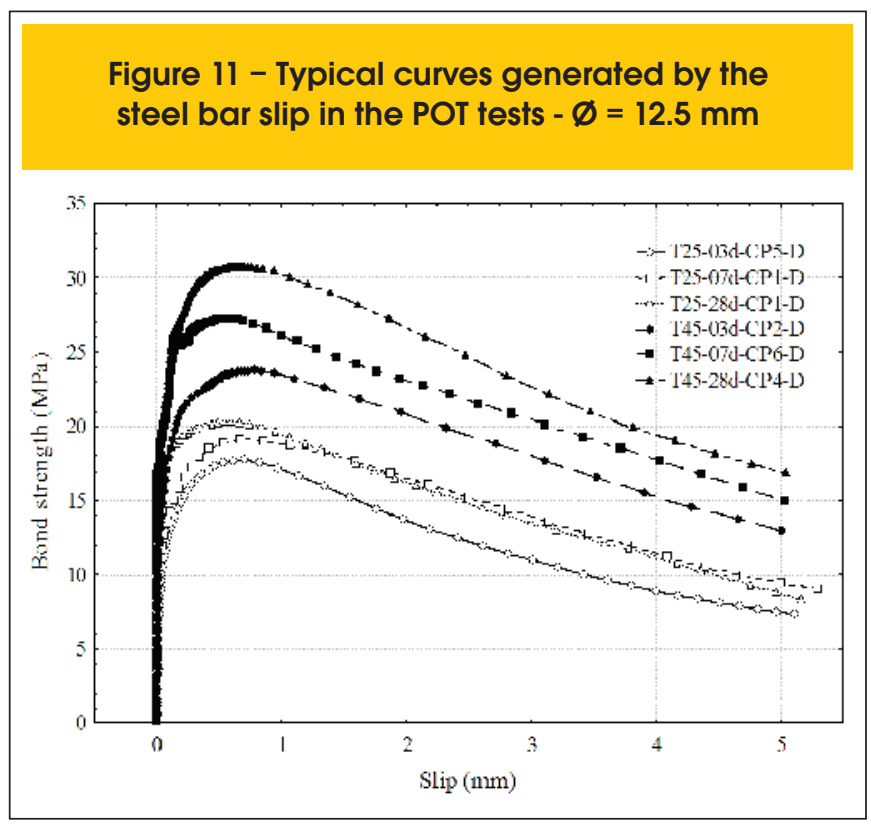

Table 4 - Average values of maximum bond strength obtained in the bond tests (POT) and average values of compressive strength of the concrete

\begin{tabular}{|c|c|c|c|c|c|}
\hline $\begin{array}{l}\text { Composition } \\
\text { of concrete }\end{array}$ & $\begin{array}{c}\text { Rupture } \\
\text { age (days) }\end{array}$ & $\begin{array}{c}\text { Compressive strength } \\
\mathrm{f}_{\mathrm{cm}} \text { (MPa) }\end{array}$ & $\begin{array}{c}\boldsymbol{\varnothing}=\mathbf{8} \mathrm{mm} \\
\tau_{\mathrm{bmáx}} \\
(\mathrm{MPa})\end{array}$ & $\begin{array}{c}\varnothing=10 \mathrm{~mm} \\
\tau_{\text {bmáx }} \\
(\mathrm{MPa})\end{array}$ & $\begin{array}{c}\boldsymbol{\varnothing}=12.5 \mathrm{~mm} \\
\tau_{\text {bmáx }} \\
(\mathrm{MPa})\end{array}$ \\
\hline T25 & 3 & $16.7 \pm 1.1$ & $10.2 \pm 2.0$ & $13.8 \pm 0.7$ & $17.6 \pm 1.4$ \\
\hline T25 & 7 & $21.1 \pm 1.6$ & $13.8 \pm 1.4$ & $16.7 \pm 1.3$ & $19.2 \pm 1.1$ \\
\hline T25 & 28 & $28.0 \pm 1.8$ & $17.0 \pm 1.1$ & $20.3 \pm 1.6$ & $23.4 \pm 2.3$ \\
\hline T45 & 3 & $33.1 \pm 1.5$ & $17.7 \pm 1.1$ & $21.0 \pm 0.5$ & $24.2 \pm 0.5$ \\
\hline T45 & 7 & $40.5 \pm 1.7$ & $21.2 \pm 0.6$ & $23.5 \pm 1.2$ & $26.9 \pm 0.7$ \\
\hline T45 & 28 & $49.9 \pm 1.8$ & $24.4 \pm 3.1$ & $27.3 \pm 1.9$ & $30.2 \pm 1.1$ \\
\hline
\end{tabular}

Table 5 - Analysis of variance (ANOVA) was performed on the results of the POT tests

Variables/interactions $(*)$

(1) Diameter of steel bar

(2) Composition of concrete

(3) Age rupture test
$(1) *(2)$
$(1) *(3)$
(2) * (3)

$(1)$ * $(2)$ * $(3)$

Error

\section{DOF}

2

1

2

2

4

2

4

86

\section{$S Q$}

671.62

1333.67

690.20

0.90

5.20

0.41

1.64

185.48
MQ

335.81

1333.67

345.10

0.45

1.30

0.21

0.41

2.16
Fc

$\mathrm{PC}>\mathrm{FC}$

DOF - Degrees of Freedom; SQ - Sum of Squares; AS - Average Square; FC - F calculated value, PC> FC is the probability of being a significant factor 
Figure 12 - Analysis of variance performed on test results obtained with the POT test. Influences of the diameter of the steel bars, concrete compositions and rupture age
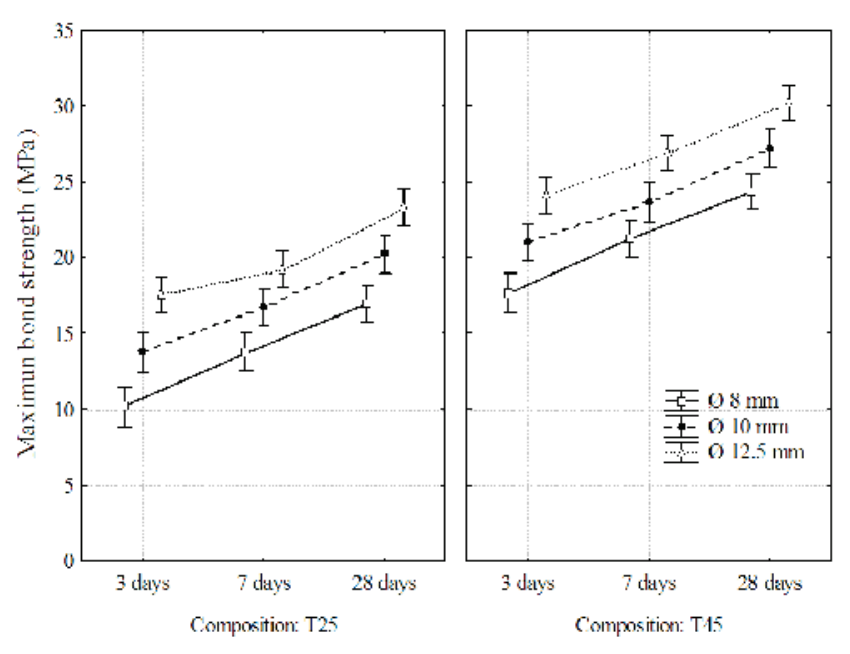

computer program. A factor can be assigned as significant if the value of " $\mathrm{Pc}>\mathrm{Fc}$ " is less than 0.05 , which means that there is a $5 \%$ chance of not being significant, in other words, $95 \%$ chance of a single factor or interaction between factors being significant.

Table 5 shows that the diameter variation, the concrete composition and the age of rupture indicated significant influence on the first order in maximum bond strength. Figure 12 illustrates the results obtained by analysis of variance (ANOVA).

In order to correlate the compressive strength of concrete with the steel-concrete maximum bond strength, linear regressions were performed between these values. Figure 13 shows the linear correlations obtained. A linear regression was performed for each individual bar diameter used, as each bar has a different anchoring capacity depending on the characteristics of each rib and different volume-surface relationship. Table 6 shows the regressions and correlation coefficients obtained. It is observed that the correlation coefficients $\left(R^{2}\right)$ obtained satisfactory values, values close to 1 . As expected, the regressions are almost parallel to each other and produce a family of curves that depend on the diameter of the steel bar. The graphical regressions in Figure 13 indicate that all angular coefficients obtained are positive, that is, for all bar diameters it is observed that there is a prominent behavior tendency that is
Figure 13 - Linear regressions of correlation between the maximum bond strength and compressive strength of the concrete, for each steel bar diameter

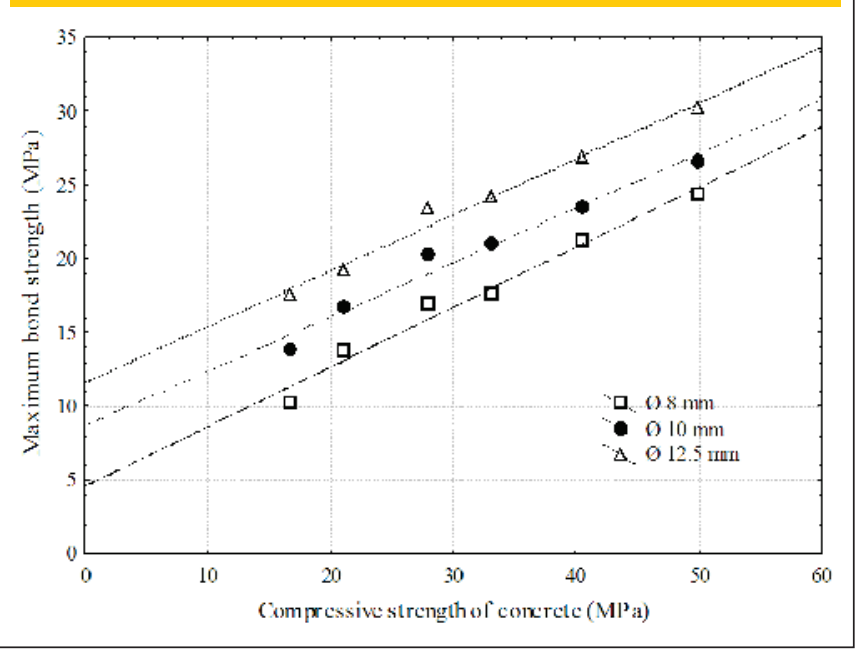

characterized by an increase in the maximum bond strength proportional to the increasing compressive strength of the concrete, at the strength range tested.

\section{Conclusions}

The correlation analysis between the maximum bond strength and compression strength of the concrete in the POT tests allow us to conclude that the POT bond tests are appropriate for estimating the compressive strength of the concrete at all ages tested. The statistical analysis showed that the maximum bond strength is influenced by changing the diameter of the bar, composition and age of the concrete. The analysis of correlations allow to conclude that the increase of maximum bond strength is proportional to the increase of the compressive strength of the concrete, while observing the characteristics of the tests, as elucidated earlier in this paper. The correlation curves obtained in this study reinforce the method proposed by Lorrain et al. (2011) [15] to perform bond tests on qualification tests of reinforced concrete due to the good proportion of the compressive strength of concrete and maximum bond strength.

It is believed that implementing this type of facilitated bond test in a complementary manner or even as an alternative to compression

Table 6 - Equations of linear regression lines and their correlation coefficients

\begin{tabular}{ccccc|}
$\begin{array}{c}\text { Diameter } \\
(\mathrm{mm})\end{array}$ & $\begin{array}{c}\text { Concrete } \\
\text { composition }\end{array}$ & $\begin{array}{c}\text { Range compression } \\
\text { strength }(\mathrm{MPa})\end{array}$ & $\begin{array}{c}\text { Linear } \\
\text { regression }\end{array}$ & $\begin{array}{c}\text { Correlation } \\
\text { coefficient }\end{array}$ \\
\hline 8 & T25 e T45 & 16.7 à 49.9 & $\tau_{\text {bmáx }}=0.41 \mathrm{f}_{\mathrm{cm}}+4.6$ & $\mathrm{R}^{2}=0.97$ \\
10 & T25 e T45 & $16.7 \grave{a} 49.9$ & $\tau_{\text {bmáx }}=0.37 \mathrm{f}_{\mathrm{cm}}+8.7$ & $\mathrm{R}^{2}=0.97$ \\
12.5 & T25 e T45 & 16.7 à 49.9 & $\tau_{\text {bmáx }}=0.38 \mathrm{f}_{\mathrm{cm}}+11.6$ & $\mathrm{R}^{2}=0.98$ \\
\hline
\end{tabular}


tests traditionally used in concrete constructions, can significantly improve quality control in construction sites, enabling quality control of concrete to be performed quickly and safely at shorter ages, "in situ".

\section{Future activities}

In the first part of this study we analyzed the maximum bond strength results from steel-concrete bond tests (POT), correlating the tests to determine the axial compressive strength of concrete. Based on the data obtained in the first part of this study confirmed the proposal by Lorrain et al. (2011) [15] to implement an alternative quality control of reinforced concrete based on bond tests is feasible to be implemented. There is a strong relationship between these variables, if other factors such as the diameter of the bars are kept constant. Based on these observations, the research group APULOT is currently attempting to determine the influence of several variables on the response of the bond test aiming to consolidate a test method. The studies not only include experimental activities but also numerical simulations in order to identify ways to implement simplified and robust tests at construction sites. In addition to the aspects studied, there is the format and preparation of the mold test, and also the pullout bar procedure (pull-out or push-out)

The second part of this paper discusses the results of another series of tests performed by the authors, in which APULOT concept is used with molded specimens using PET bottles as a mold to demonstrate that the tests can be performed with low technological material. The third step analyzes the best methods to implement the methodology at construction sites, which can provide good reproducibility and reliability.

\section{Acknowledgements}

FAPESP (Fundação de Amparo à Pesquisa do Estado de São Paulo); CNPQ (Conselho Nacional de Desenvolvimento Científico e Tecnológico);

LCEC (Laboratório CESP de Engenharia Civil - Ilha Solteira/SP);

Civil Engineering Central Laboratory - UNESP / Ilha Solteira/SP;

ArcelorMittal for providing the steel bars;

Holcim do Brasil for providing the cement;

Grace Concrete Products for providing the superplasticizer.

\section{Nomenclature}

A - Maximum height of the rib $(\mathrm{mm})$;

$A_{g t}$ - Strain failure of steel bar (\%)

$\beta$ - Horizontal rib angle (inclination) (');

APULOT - Appropriate PULL-Out Test;

$F$ - Pullout force $(\mathrm{kN})$;

$l_{\text {exp }}$ - Experimental bond length $(\mathrm{mm})$;

e - Rib spacing $(\mathrm{mm})$;

$\varnothing$ - Diameter of steel bar $(\mathrm{mm})$;

$E_{c}$ - Elastic modulus of elasticity of concrete (GPa);

POT - Pull-Out Test (RILEM/CEB/FIP RC6: 1983);

$f_{c}$ - Compressive strength of concrete (MPa);

$f_{c m}^{c}$ - Compressive strength of concrete average (MPa);

$f_{c t m}$ - Tensile strength by diametral compression average (MPa);

$f_{s y}^{c t m}-$ Yield stress of steel (MPa); $f_{\text {st }}$ - Failure Strength of steel (MPa);

$\tau_{b}$-Steel-Concrete Bond strength (MPa);

$\tau_{\text {bmáx }}$ - Steel-Concrete Maximum bond strength (MPa).

\section{Referências bibliográficas}

[01] AMERICAN CONCRETE INSTITUTE. ACI 408R: Bond and development of straight reinforcing bars in tension. Farmington Hills, 2003

[02] ASSOCIAÇÃO BRASILEIRA DE NORMAS TÉCNICAS. NBR 7480: Aço destinado a armaduras para estruturas de concreto armado - Especificação. Rio de Janeiro, 2007

[03] NBR 8522: Concreto - Determinação do módulo estático de elasticidade à compressão. Rio de Janeiro, 2008.

[04] NBR 7222: Concreto e Argamassa Determinação da resistência à tração por compressão diametral de corpos de prova cilíndricos. Rio de Janeiro, 2010.

[05] NBR 5739: Concreto - Ensaios de compressão de corpos de prova cilíndricos. Rio de Janeiro, 2007.

[06] NBR 5738: Concreto - Procedimento para moldagem e cura de corpos de prova. Rio de Janeiro, 2003.

[07] CAETANO, L. F. Estudo do comportamento da aderência de elementos de concreto armado em condições extremas. 2008. 178f. Dissertação (Mestrado em Engenharia) - Programa de Pós-Graduação em Engenharia Civil, Universidade Federal do Rio Grande do Sul (UFRGS), Porto Alegre, 2008.

[08] COMITÉ EURO-INTERNATIONAL DU BÉTON. RILEM/CEB/FIP RC6: Bond test for reinforcement steel - 2 Pull-out test. Paris, 1983.

[09] FÉDÉRATION INTERNATIONALE DE BÉTON. FIB: Bond of reinforcement concrete, State-of-art report. Bulletin No 10. Lausanne, Switzerland: FIB, 2000. $427 p$.

[10] FERGUSON, P. M. Bond Stress - The State of the Art. ACI Proceedings Journal, v.63, n.11, p. 1161-1190, 1966.

[11] GRAEFF, A. G., Avaliação experimental e modelagem dos efeitos estruturais da propagação da corrosão em elementos de concreto armado. 2007. $184 \mathrm{f}$. Dissertação (Mestrado em Engenharia) - Programa de Pós-Graduação em Engenharia Civil, Universidade Federal do Rio Grande do Sul (UFRGS), Porto Alegre, 2007.

[12] HELENE, P.; TERZIAN, P. Manual de dosagem e controle do concreto. São Paulo: PINI, 1992. 349p.

[13] LEONHARDT, F.; MÖNNIG, E. Construções de concreto - Princípios básicos do dimensionamento de estruturas de concreto armado. Rio de Janeiro: Interciência, 1977. 305p.

[14] LORRAIN, M. S.; BARBOSA P. M. Controle de qualidade dos concretos estruturais: ensaio de aderência aço-concreto. In: Revista Concreto \& Construções, São Paulo, N51, $3^{\circ}$ trimestre, p. 52-57, 2008.

[15] LORRAIN, M. S. ; BARBOSA, M. P. ; SILVA FILHO, L. 
C. P. Estimation of compressive strength based on Pull-Out bond test results for on-site concrete quality control. IBRACON Structures and Materials Journal, v. 4, p. 4, 2011.

[16] LORRAIN, M. S. ; CAETANO, L. F. ; VALE SILVA, B. ; GOMES, L. E. S. ; BARBOSA, M. P. ; SILVA FILHO, L. C. P. Bond strength and rib geometry: a comparative study of the influence of deformation patterns on anchorage bond strength. In: PCI Annual Convention \& 3rd International FIB Congress FIB, Washington D. C., 2010

[17] SILVA FILHO, L. C .P. ; VALE SILVA, B. ; DAL BOSCO, V. I. ; GOMES, L. E. S. ; BARBOSA, M.P. ; LORRAIN, M. S. Analysis of the influence of rebar geometry variations on bonding strength in the pull-out test. In: Bond in Concrete 2012 - Bond, Anchorage, Detailing. Fourth International Symposiumn BIC/FIB, Brescia, Italy, 2012.

[18] SOROUSHIAN, P.; CHOI, K.; PARK, G.; ASLANI, $F$. Bond of deformed bars to concrete: effects to confinement and strength of concrete. ACl Materials Journal, v.88, n.3, p. 227-232, 1991.

[19] VALE SILVA, B. Investigação do potencial dos ensaios APULOT e pull-out para estimativa da resistência a compressão do concreto. 2010. 178 f. Dissertação (Mestrado em Engenharia) Faculdade de Engenharia da Universidade Estadual Paulista (UNESP), Ilha Solteira, 2010. 